Revista Española de Antropología Americana ISSN: 0556-6533

https://doi.org/10.5209/reaa.64968

\title{
Ingenuity and Ambivalence in Maya Writing
}

\author{
Stephen Houston ${ }^{1}$
}

Recibido: 27 de febrero de 2019 / Aceptado: 15 de marzo de 2019

\begin{abstract}
Scribal reception and status among the Classic Maya drew on subtle skills and playful games. But it also rested on an evident understanding that scribes (or sculptors) and their provincial patrons needed to obey their superiors. Certain clues indicate that the producers of script existed within established obligations of tribute, for written memorials as well. Elsewhere, myths provide enduring templates for humanity, and that was no less true for the Classic Maya. Historical figures merged with mythic scribes, and, to judge from unusual texts and images, the powers of the literate could be neutralized by physical replacement or even the threat of execution.
\end{abstract}

Keywords: Classic Maya art and writing; scribal reception; social control of literacy; mergers of elite and mythic identity.

\section{[es] Ingenio y ambivalencia en la escritura maya}

Resumen. La aceptación y estatus de los escribas entre los mayas clásicos se basaba en sutiles habilidades y juegos lúdicos. Pero también descansaba en un entendimiento evidente de que los escribas (o escultores) y sus mecenas provinciales tenían que obedecer a sus superiores. Ciertas pistas indican que los productores de textos escritos estaban incluidos como tales en obligaciones tributarias establecidas, como también lo estaban los memoriales. En otros lugares los mitos proporcionan modelos duraderos para la humanidad, y eso no fue menos cierto para los mayas clásicos. Figuras históricas se fusionaron con escribas míticos y, a juzgar por textos e imágenes inusuales, los poderes de quienes conocían la escritura podían neutralizarse mediante su reemplazo físico o incluso la amenaza de ejecución.

Palabras clave: Arte y escritura de los mayas clásicos; tratamiento del escriba; control social de la capacidad de escribir y leer; fusiones de identidad entre la élite y los dioses.

Contents. 1. Puzzle Writing. 2. Tributary Texts. 3. «Kill All the Lawyers». 4. References.

How to cite: Houston, Stephen. 2019. «Ingenuity and Ambivalence in Maya Writing». Revista Española de Antropología Americana 49 (número especial): 225-240.

When talent departs, we all diminish. The passing of Alfonso Lacadena takes away a present-day «scribe» who had, in a career cut short, uncovered many features of Maya writing. Much was still to come from Alfonso. The loss of future insights remains a source of grief-if not remotely as painful as the loss of a good friend. Yet his example, creativity, and interest in the social setting of writing inspire me to write this essay in his memory. Here I address two, opposed tendencies in Maya script: a few glyphic texts could be ingenious, amusing or even light in mood, and, on occa-

\footnotetext{
1 Brown University. Stephen_Houston@brown.edu
} 


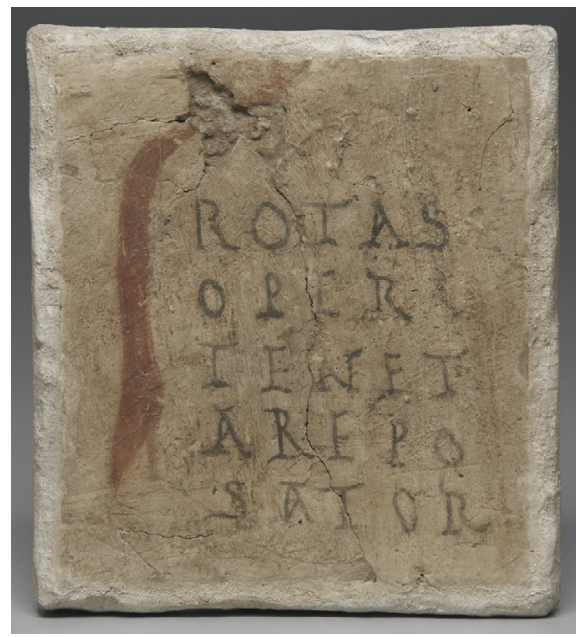

Figure 1. Sator Square from Dura-Europos, Syria, c. AD 165-256 (Yale University Art Gallery, \#1933.298, Public Domain).

sion, in other texts, their political context registered darker, oppressive overtones. Clearly, scribes and sculptors operated within systems of royal patronage and tributary demands (Houston 2016a: 403-407, fig. 13.11); at least one such figure appears to have slotted into a mythic identity of inevitable humiliation or defeat ${ }^{2}$. Inducing admiration, Maya glyphs had a potential for drollery. But they also reflected worries, even demands, about who should control their production.

\section{Puzzle Writing}

Transparency is not always the aim of writing. By their ingenuity, signs can also baffle and please, taking readers into a concealed but ultimately accessible message (Turchi 2014:31). Sometimes the puzzle relates to esoteric matters or «magical» diagrams, such as the «Sator squares» from the ancient world. These devices were fourdirectional palindromes, read left-right, right-left, up-down, down-up, invoking, perhaps, deities, personal names, and Latin words, and even some hint of Hebrew verbs (Last 1952: 93 [for compilation of such devices]; Griffiths 1971: 8; Vinel 2006: 192-193). Examples exist in far-flung places like Pompeii, Dura-Europos in Syria (Figure 1), and Cirencester, England. Decidedly pre-Christian, Sator squares even infiltrated Christian settings of the Early Modern period (St. Barnabas, England; Howse 2015). As symbol and puzzle, they had an ability to capture people's imaginations, thus sustaining their use. Their appeal carried them across millennia.

The Classic Maya seem to have had fun too. The setting is not a slab or painted wall at Pompeii but a pot that is among the most finely painted to survive from the Classic period. It is hopelessly subjective to speak of the greatest Maya painting on a pot and equally futile to engage in an aesthetic tournament between past and present standards of beauty. But here, in this instance, the hyperbole fits (for an image, see

\footnotetext{
2 This essay draws on three related blogs in Maya Decipherment: Ideas on Ancient Maya Writing and Iconography, an online forum sponsored by David Stuart. Conversations with David, Simon Martin, Mary Miller, Karl Taube, and Marc Zender shaped those preliminary thoughts. The current draft was written during a leave of absence granted by Brown University. I also held the Kislak Chair in the Kluge Center at the Library of Congress and a fellowship from the American Council of Learned Societies.
} 
Figure 2. Detail of vase (private collection, rollout, BAMW Photography).

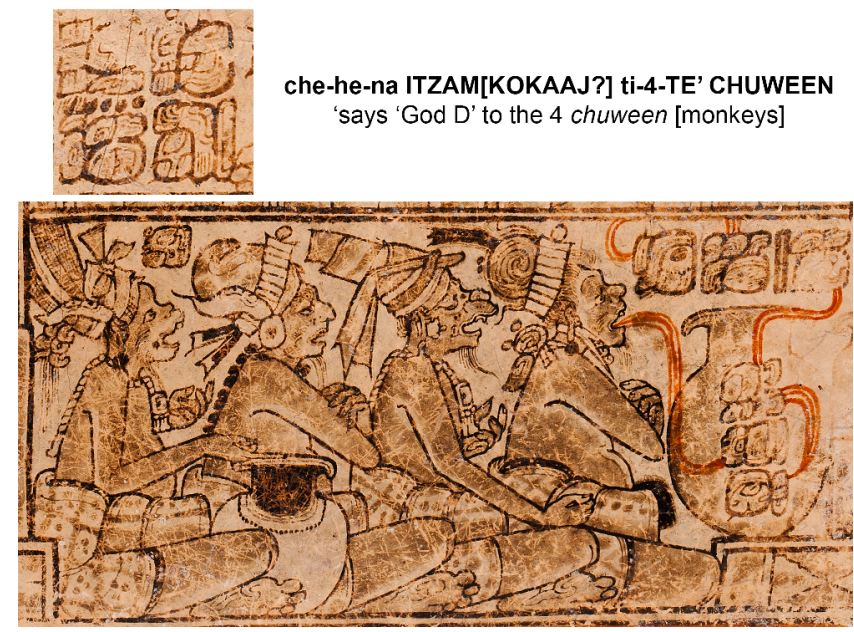

Coe and Houston 2015: pl. XVIII; also Boot 2008, the first to acquire, study, and disseminate images of the ceramic). Dating to about AD 750, the vase has a named calligrapher, 'RABBIT'-bu (T'ulub?). Such references are rare. Its presence here signals special esteem for the painter. The pot belonged, as do many of the most carefully executed pot paintings, to a youth (Houston 2018). In this case, the boy or teenager was associated with the Peten Itza ('i-IK'-'a) region of northern Guatemala.

This is not the place to discuss in full the rich complexities of the pot. Its fascinating spellings deserve separate study. But worth noting are the unusual pronouns - an absolutive -eet for the 2nd-person singular, «you», another absolutive -oon, «we» (Boot 2008: 12) - and the late collapse or near-homophonic play of distinct words (juun [«one»] hu'n [«paper, book»] > huun?, highlighted here in 1 pik ka ['] nal k'uh, 1 pik kabal k'uh, «8,000 Celestial Gods, 8,000 Terrestrial Gods». (In 1986, the author noted a similar alternation of the number «1» and a sign for «book» on two ceramics, one in a private collection in Guatemala City.) The image and its accompanying texts create a sense of immediacy through spirited conversation.

What draws particular attention is a set of four Monkey figures conversing with God D on his throne (Figure 2). A text near God D makes it clear that he speaks to an assembled group of Chuween, doubtless the four Monkeys seated to lower left ${ }^{3}$. The TE', «tree, wood», in this expression probably serves as a numeral classifier for the number «4». However, as an alternative explanation, the Popol Vuh recounts the transformation of an earlier set of «wooden» people into monkeys, for «their flesh was merely wood» (Christenson 2007: 90; see also Boot 2008: 28). Is that

\footnotetext{
3 The che-he-na spelling is probably not recording, as some scholars suggest, the first person «I», -een, as in «I say» (cf. Hull et al. 2009: 36). On ceramic texts and Ceibal Hieroglyphic Stairway 1, among other places, a switch from an involved declaration («I say») to the statement of a name may require too many pivots in point-of-view: not unprecedented, but awkward and difficult to follow. For this reason, an interpretation by Nikolai Grube may work better: «así dice», akin to Ch'ol che'en (Grube 1998: 549). Furthermore, unusual pronouns in Maya script tend to involve divine or «mythic» actors, or those operating in a more remote if non-mythic past. Piedras Negras Panel 3 is a pertinent example, for it depicts a number of people long dead at the time the panel was carved. The first public exposition of such pronouns was in a talk for the Society of American Archaeology meetings (Houston and Stuart 1993). Houston had found pre-vocalic, second-person pronouns (e.g., 'a-wi-chi-NAL, on a vase from Burial 196 at Tikal; see K8008 in Justin Kerr's catalogue of rollout photographs), Stuart first-person (e.g., ni-CH'AM-wa, K1398), and we elected to present them together.
} 


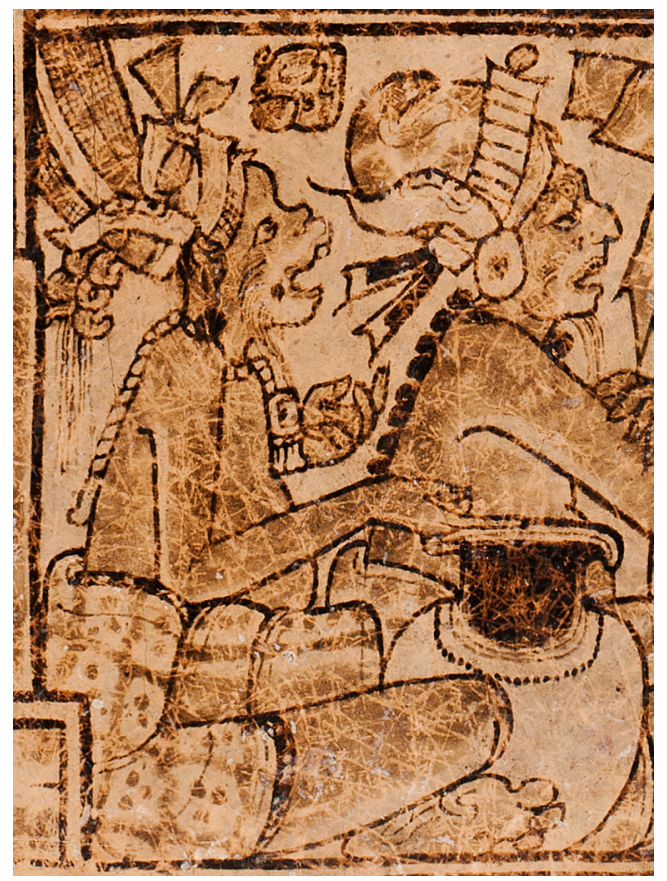

Figure 3. The drinking monkey glyph (private collection, detail, BAMW Photography).

the reference here? Nothing on their bodies would indicate wooden substance. But the contrastive appearance of the monkeys is intriguing, veering from human and elderly to simian or deity-like. A few are elderly, as shown by their beards, and one may be younger. The varied faces, along with the differing headdresses, hint at the poorly understood subtleties of mythic Monkeys. The figure to far left, presumably of lowest rank, has a large olla (liquid jar) in front, as does the monkey to the far right. A lively touch is that the small simian head-glyph above the latter combines a glyph for consumption - a small face with water sign in the mouth, probably read UK', after a reading by David Stuart — and the monkey's head itself (Figure 3; see Houston et al. 2006: fig. 3.5). He must have been thought an unusually thirsty fellow.

The lead Monkey is central to our discussion of puzzle writing (Figure 3). He is the only figure on the vase whose mouth both opens and emits a flow of... what? One suggestion is that it forms «a stream of red liquid» (Boot 2008: 8). More likely, it corresponds to speech scrolls in Maya imagery, a means of showing a forceful (cued by the red?) if invisible utterance and, at times, a way of linking depictions of speakers to a glyphic text (Houston et al. 2006: 154-163). The glyphs are, with a few exceptions, relatively easy to read, beginning with YAX-k'a-xa WINIK-ki, yax k'ax winik, "the first jungle/forest men». (But note: aside from its resonance with the colonial K'iche' book, the Popol Vuh, which refers to primordial monkey people, $k^{\prime} a x$ is more of a Yukatekan word [Barrera Vásquez et al. 1980: 387]). The text follows with: u-ti-ya, uhtiiy, «it happened [at]»; a likely independent pronoun, HA'-'o?-ba, $h a$ 'o' $b$, «those», a reading first pointed out to me by David Stuart (e.g., Hull et al. 2009: 38-39; Mora-Marín 2009: 120, for spelling, see Robertson et al. 2007: 48); and a mythic place name, possibly featuring the flower of the tobacco plant (Simon Martin, personal communication, 2013; see Stuart and Houston 1994: 
77, fig. 92) ${ }^{4}$. Such independent pronouns occur in a number of texts (e.g., Museum of Fine Arts, Boston, 1988. 1183, as HA'-'o-ba YAX-K'UH YAX-AJAW-wa, $h a^{\prime}$ o'b yax k'uh, yax ajaw, «those, the first gods, the first lords»). The wa-wa-li is more difficult to interpret, but it may record w-aw-il, «my shouts [howling] »? or «my shouters [howlers?]», aw being a root for hearty vocalizations going far back to the beginnings of Mayan languages (Kaufman and Norman 1984: 116; for the pronoun, a pre-vocalic first-person singular, see Law 2014: table 31). A few other texts appear to use this expression, including two versions on a pot with inebriated (and noisy?) youths (K1092): wa' ${ }^{2}$-wa-li and wa-wa-IL, and another on a vase from Tikal, wawa-IL/li (K8008, MT176).

The enigma is in their reading order. A conventional view would arrange them as in the figure to the left: left to right, top to bottom (Figure 4). But that is almost certainly wrong. The speech scroll - in multiple strands to signal sputtering or the flow of distinct words? - issues from the mouth, then, in the figure to lower right, touches the glyph for «First Forest». The next glyph, «person», is directly below, emitting its own scroll that winds its way up to the «it happened [at]», followed by the place name at \#4. What do we do with the ha'o'b and wawil/wawal? The looping strands, which go «off-scene» only to reappear at \#6, suggest that the former came before the latter. By the conventions of this pot, strands appear to be start slender, then expand.
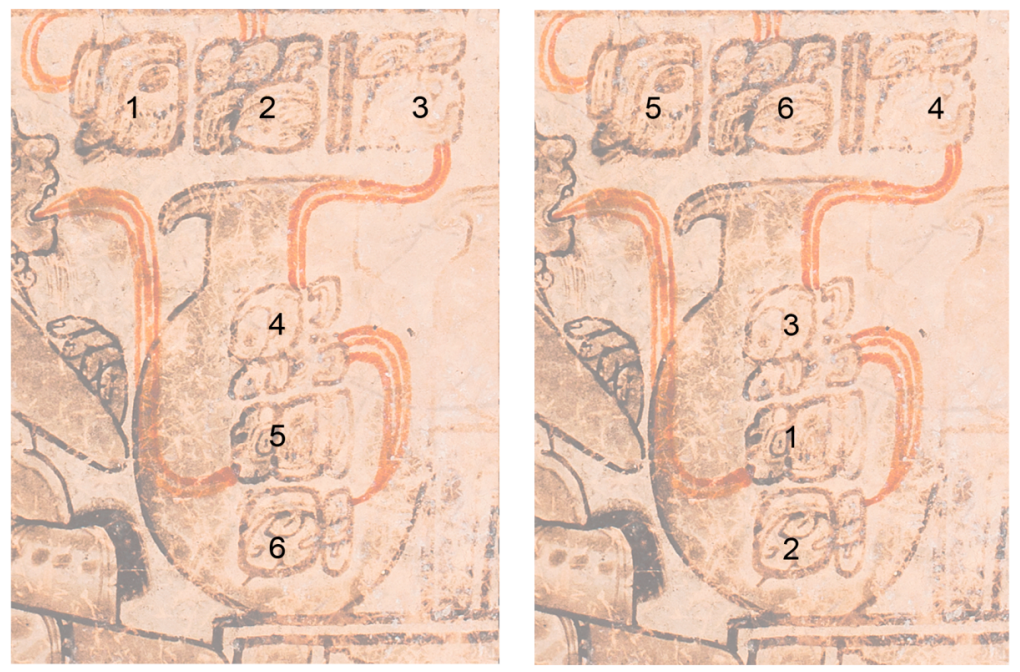

Figure 4. Comparison of two possible reading orders (private collection, details, BAMW Photography).

\footnotetext{
4 The spellings of $h a$ - ' $i$ may not yet be fully resolved. One view interprets them two separate morphemes, $h a$ ' and ' $i$ (e.g., Hull et al. 2009: 36, 38, albeit with provisos; Mora-Marín 2009: fig. 4). This would provide a deictic clitic at the end, an $-i$, «this, here», reconstructed for Common Mayan (Mora-Marín 2009: table 4). But a late version from Caracol Ballcourt Marker 3 ( $h a$ - ' $a$ ?) suggests an alternative: that the earlier form was haa', as triggered by disharmony and the appended ' $i$ syllable. By a process well attested at Copan and Naranjo, this term might later have shortened to $h a^{\prime}$. A challenge is that, on present study, no such length is reconstructible for earlier forms of ha' (Kaufman and Norman 1984: 139).
} 
Of course, it is possible that \#5 and \#6, came prior to the others, but the scrolls from the mouth suggest otherwise. The key is to follow their twists and turns.

For scholars, writing is serious stuff. Careers collapse or soar on the fortunes of a decipherment or after review of a solemn bin of essays. Yet Maya glyphs were about wit too, as playful as any monkey god. Readers would start this text, and let go. The sinuous red lines carried them away, in a scribal frolic that continues to charm: this is a secret but, to the knowledgeable, one within reach. The image on this vase is curious in another respect, however. The apparent scribes are not these monkeys, who serve in that capacity elsewhere, but, facing them, a menagerie of other creatures, a dog (OOK-ki), an opossum (u-chu), and a vulture (u-su). The vulture holds a single sheet of numbers, the opossum cradles a book, and the whiskered dog bears a small brush in his headdress. Is some transfer of knowledge or skill implied here, the removal or displacement of that skill from the monkeys, or even a babbling misperformance by the monkeys, their words mostly out of order? At the least, the open mouths of figures on the pot point to vigorous speech. Now in silent ink, painted on slipped clay, the scene showed a clamor of loud voices.

\section{Tributary Texts}

At Calakmul, Mexico, sculptures were not just made by craftsmen who recorded their contribution via «signatures» or «autographs» (Stuart 1989; also Houston 2016a). Several sculptures probably came from political subordinates, in offerings shipped by magnates to the overlord (Martin et al. 2015; Zender et al. 2016: 46-47) ${ }^{5}$. One possibility is especially noteworthy, Calakmul Stela 51, a monument with unusual, almost voluptuous touches. Exuberant volutes roll through the ruler's hair, in what may be a sycophantic nod to royal vanity. The surface puffs out with striking, volumetric handling. And, as though bursting forth, elements of the headdress extend beyond the sculptural frame (see, too, Stela 89, created by the same carvers; Ruppert and Denison 1943: pls. 50c, 53b).

This is virtuoso work, meant to impress, and perhaps the royal beneficiary above all. As yet, there is no adequate, in toto presentation of the Calakmul monuments. Simon Martin (2014) is refining the history of the site and its region, and that work is likely to be definitive on current evidence ${ }^{6}$. But we can say this: Stela 51 was of some size, $4.12 \mathrm{~m}$ in overall height, $3.10 \mathrm{~m}$ in length of carving. Stela 89 , doubtless delivered at the same general time (its recorded date is 274 days after Stela 51's), is half that, at $1.55 \mathrm{~m}$ in length of carving. Did this disproportion have something to do with ease of transport or reducing the physical burden of that shipment? In fact, the stone appears to have been «[h] ewn from a dense, durable limestone, presumably imported from some distance» (Martin and Grube 2008: 113). Unfortunately, epigraphers, the author included, seldom, if ever, record quantitative measures of stone hardness. They should. Anomalies might reveal themselves, as in the case of the

\footnotetext{
The shipment of carvings existed alongside the option of sending out carvers to do their labors elsewhere (Houston 2016a: 407, fig. 13.11).

6 To be sure, there is Marcus (1987). To my critical eye, this monograph offers a model of how not to do such a report: brief, unreliable, under-cited, and poorly illustrated. Unlike Egyptology or allied disciplines, we do not yet have an adequate manual for Maya epigraphy (cf. Caminos 1976; Cooley 2012; Vértes 2014) and only a preliminary if ongoing discussion about minimal or maximal standards of recording (Graham 1975: 11-14).
} 
re-carved Panel 10 at Dos Pilas. That sculpture, «evidently of nonlocal material», a "fine-grained and dense limestone», is wholly different from the softer stone in other carvings at the site (Houston 1993: 72, fig. 3-1). The re-carving hints that Panel 10 was transported from elsewhere, something that might have been done, as at Aguateca, Guatemala, for the sculptures of vanquished, enemy kingdoms (Houston 2014).

Another tributary text comes to mind. Step IV on Yaxchilan Hieroglyphic Stairway 3 has elicited a sense of anomaly since its full publication by Ian Graham (1982: 170). The style is notably ham-handed in comparison to other carvings on the stairway (Figure 5). Rather than the tidy layout of other treads, which link thematically to the presentation of important captives, these glyphs appear in slovenly manner. Signs slope and sag, their outlines bulge. The look is less of disciplined carving than painterly «facture», a reflection of originals rapidly executed in pigment. Few rows follow the same alignment, and some glyph blocks vary greatly in size. Even the final column bows to the right before coming back to its intended vertical alignment. There is also a real chance that the limestone itself differed from other treads. According to Ian Graham (1982: 165), its weathering is quite distinct from the other, lower steps of the stairway. This indicates harder stone or, perhaps, a later placement. (Such insertions are known at Yaxchilan: Lintel 21, from the Late Classic period, occurs with Early Classic companions in the lintel series of Structure 22.) Were imported stones usually harder so as to avoid damage en route? Step IV also has its own dedication date of 9.14.11.10.1, and for an unusual «owner», a ruler, Shield Jaguar III, in impersonation mode, i.e., in the guise of a god.

The concluding phrases of the text are far smaller than those referring to royalty such as Shield Jaguar (B4), his mother (A5-B5), and his father, Bird Jaguar III (B6, Figure 6). They would seem to follow a sumptuary pattern: the ensuing names belong to at least one person of lesser, sajal status. Thus, reduced social importance $=$ smaller signs, but also with considerable, ill-controlled variance of dimensions. The text is unambiguous, stating that the carving was raised up ( $t$ ' $a b$ but without the usual yi syllable as a suffix or infix, perhaps a problem in Graham's drawing). It belonged to someone named «guardian of Yellow(?) Bat», who was in the company (yi-ta-ji) of 12 Pat, a term David Stuart has linked to tribute (Stuart 1998: 384, fig. 6). To judge from the toponymic phrases at the end, one or both of these figures came at least in part from the Yaxchilan kingdom.

The descriptive for the carving or kind of sculpture (u-k'a?-li) is known elsewhere (e.g., Xcalumkin Lintel 1:G1, Xcombec «St. 1»:C3), although it tends to be rare at sites to the south of the Puuc hills or the Campeche coast. One, for example, may occur at Naj Tunich (u-k'a ha in Drawing 51 [Stone 1995: pl. 11]). Nonetheless, it is fair to say that, after a discussion with David Stuart, the reading remains opaque or at least debatable. Stuart and I are both dubious that this relevant glyph for the monument type is simply a syllabic k'a. That matter can be left for later. What commands our attention is that this slab, so wildly discrepant from its neighboring treads, seemingly of different stone, refers to its possession by a subordinate who uses a title of war-he is the guardian of a captive ${ }^{7}$. Another figure, employing a possible title

The yatz'in? might include another pronoun (y-), signaling the presence of yet a third name in this text («guardian of Yellow? Bat» as the atz' in of a sajal). An even finer analysis might see three morphemes: $y$ - (third-person pronoun), ' $a$ (an «agentive» particle, sometimes expressed as $a j$ ), and $t z$ 'in («sister-in-law» or even «manioc», Hopkins et al. 2011: 248, 249; Hull 2016: 458). My suspicion is that this is an over-analysis, although it could relate to sororal ties among elites. Combinations of $y$ - and ' $a$ are also attested in possessive forms of the so-called 


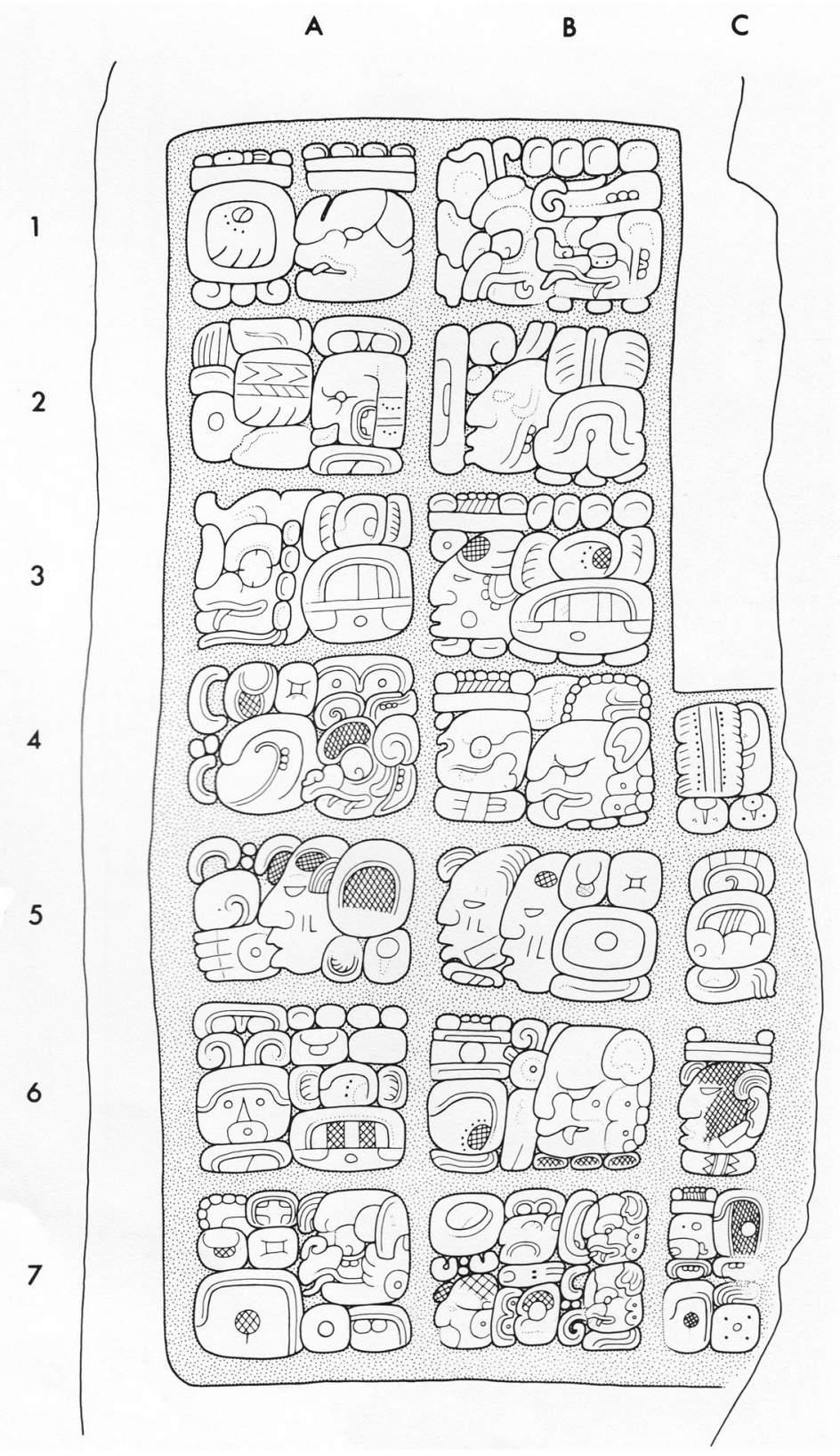

Figure 5. Yaxchilan Hieroglyphic Stairway 3, Step IV (drawing by Ian Graham, (C) President and Fellows of Harvard College, Peabody Museum of Archaeology and Ethnology, PM \# 2004.15.6.7.33).

for tributaries (12 pa-ta), comes second. As at Calakmul, the lords of Yaxchilan may have exhibited stones brought at some effort from subordinate sites. Those carvings were either extracted from subsidiary lords or given by them in respectful service. 

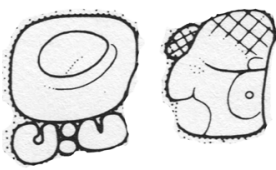

T'AB

'Initial Sign’
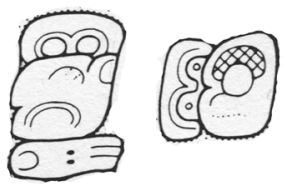

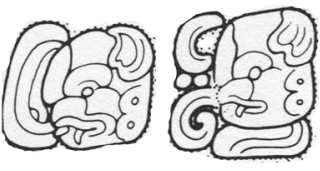

u-CHAN K'AN?-SUUTZ' ya-tz'i?-ni

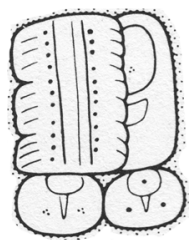

sa-ja-la

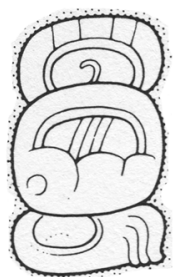

yi-ta-ji

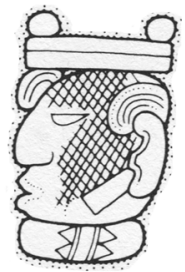

12-pa-ta
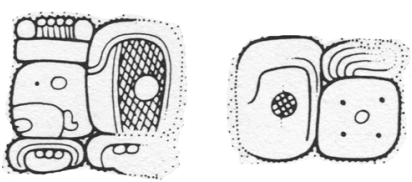

AJ-TAHN-na CH'E'N

?-ni-bi

Figure 6. Yaxchilan Hieroglyphic Stairway 3, parsing of final phrase in Step IV (drawing by

Ian Graham, (C) President and Fellows of Harvard College, Peabody Museum of Archaeology and Ethnology, PM \# 2004.15.6.7.33).

\section{3. «Kill All the Lawyers»}

...said Dick the Butcher, a miscreant in Shakespeare's Henry VI, Part II, act IV, Scene II, Line 73. What Shakespeare meant and whether this was side-splitting to a late Elizabethan audience are matters best left to specialists. What concerns us here is the treatment of scribes, keepers of recondite knowledge and official memories, as well as the clerks, we presume, in adjudications among the Classic Maya. Since the 1980s, Mary Miller has suggested that artists served as tribute or war booty in dynasties of the time (Schele and Miller 1986: 219-220; also Miller 2000; Miller and Brittenham 2013: 110,112). This proposal found favor with Kevin Johnston, who also reported on the possible mutilation of scribal hands. Cruel mistreatment removed, not their skill, but any capacity to apply it in the future (Johnston 2001) ${ }^{8}$. Few scholarly studies make their way into a poem for The New Yorker, but this one did, and by a winner of the Pulitzer Prize (Williams 2001). The complex movements and political subordination of sculptors have grown clearer with research into such «loans» and the cross-polity transfers of sculptural talent (Houston 2016a: fig. 13.11; see also Zender et al. 2016: 46-47, fig. 10). Some carvings may even have come as tribute from subordinate lords.

\footnotetext{
8 Visitors to Saint Basil's Cathedral in Moscow will hear the (probably) apocryphal story of its architect, Postnik Yakovlev (Постник Яковлев), blinded by Ivan the Terrible so that nothing so beautiful would be built again (for a more grounded account, see Flier 2008: 43-45). That the Maya mutilated scribes is plausible - there are caches of finger bones (or a scene of blood-letting from hands in Room 1 at Bonampak-but indecisive. It is hard to know who lost their fingers (the deposits are mute on this score) or why a person, the baah-took', was slicing at (complete) digits in the Bonampak murals.
} 
That phrase, «kill all the lawyers», brings us back to the vulnerabilities of Maya kingdoms. One example occurs on the front of Moral-La Reforma Stela 1, now on display in the Museo de Antropología «Carlos Pellicer Cámara», Villahermosa, Tabasco (Andrews 1943: figs. 13, 27; Pavón Abreu 1945: fig. 3; also Martin 2003: 46-47). Located near the Río San Pedro Mártir, the city of Moral-La Reforma has acquired a bewildering variety of names: Reforma II, Reforma, Moral, Morales, Balancán-Morales, Acalán. By fiat of the Mexican authorities, it is now simply MoralLa Reforma. The city contains at least five stelae and an Emblem that I identified in 1983 but did not have a chance to publish. Stela 1 dates to April 9, AD 756 (Julian, 9.16.5.0.0 8 Ajaw 8 Zotz'), although it offers other, probably earlier dates that are impossible to reconstruct in the absence of better images. As with many Maya sites, the corpus of monuments at Moral-La Reforma is both readily accessible and in bad need of adequate renderings. Drawings from the 1940s remain a basic source-not a good sign. Fortunately, there are superb vignettes in an article by Simon Martin (2003).

Stela 1 in particular has one of the most northerly examples of a sculptor's signature (front, just by the K'awiil scepter of the dancing ruler), as well as a complex embroidery of dates in addition to its Initial Series. I count at least four such temporal hooks. The back of the carving displays what looks to be a capture, the victor in unusually active pose (Figure 7). His foot presses against the groin of the captive, whose mouth opens in agony. He may even be in full howl. Certainly his head pulls back and lower lip juts up. Yet this may not be an image from battle, and a closer analogy is to gladiatorial combat (Taube and Zender 2009; Houston 2016b). Both figures grasp what appear to be stone saps. One of the weapons, held aloft by the victor, will soon land on the face or glance off the raised elbow of the victim. A strip of $k a b$ or earth signs below, passing along all sides of the stela, provides a sense of firmament. On this side of the stela it would also absorb blood. Why these signs were thought necessary, as, for example, at Dos Pilas and Calakmul, is poorly understood. Did they refer to some specific setting or quality of surface? The event must have been explained by the vertical text to the far right. The text at left names the loser, a figure labeled Itzam K'anahk, a royal epithet at Piedras Negras (Martin 2003: 47). But a Piedras Negras affiliation is unlikely here in that the following Emblem does not match the usual form of that spelling. The name does recall «Itzamkanak», a large community some $50 \mathrm{~km}$ northeast of Moral-La Reforma, visited by Cortés on his way south to deal with rebels in Honduras (Scholes and Roys 1968: 110-111, map 3). Yet the connection is distant in time and involves a toponym rather than a personal name.

The combat covers only one surface. The main image curves around the sides. This scene is visually dominant, although, in epigraphic terms, the back of the stela carries the Initial Series anchoring all dates on the stela. The main figure, whose name may be jo?-wo-KAN-K'AWIIL (Martin 2003: 47), dances between two seated figures, both captives. Each has arms bound behind the back and looks up to the person controlling their destiny (Figure 8). The differential in size is notable. It may represent their relative size, and perhaps the youth or dwarfishness of the figure to the left.

The truly unusual feature is that both seem to have tails. There must have been a frisson when the viewer saw, at first, human figures and then, glancing around the sides, a wholly non-human attribute. The figure to the left is eroded and thus more 
Figure 7. Moral-La Reforma Stela 1, back (photograph by Ian Graham, (C) President and Fellows of Harvard College, Peabody Museum of Archaeology and Ethnology, PM \# 2004.15.1.1712.1).

Figure 8. Moral-La Reforma Stela 1, front: Bound captives

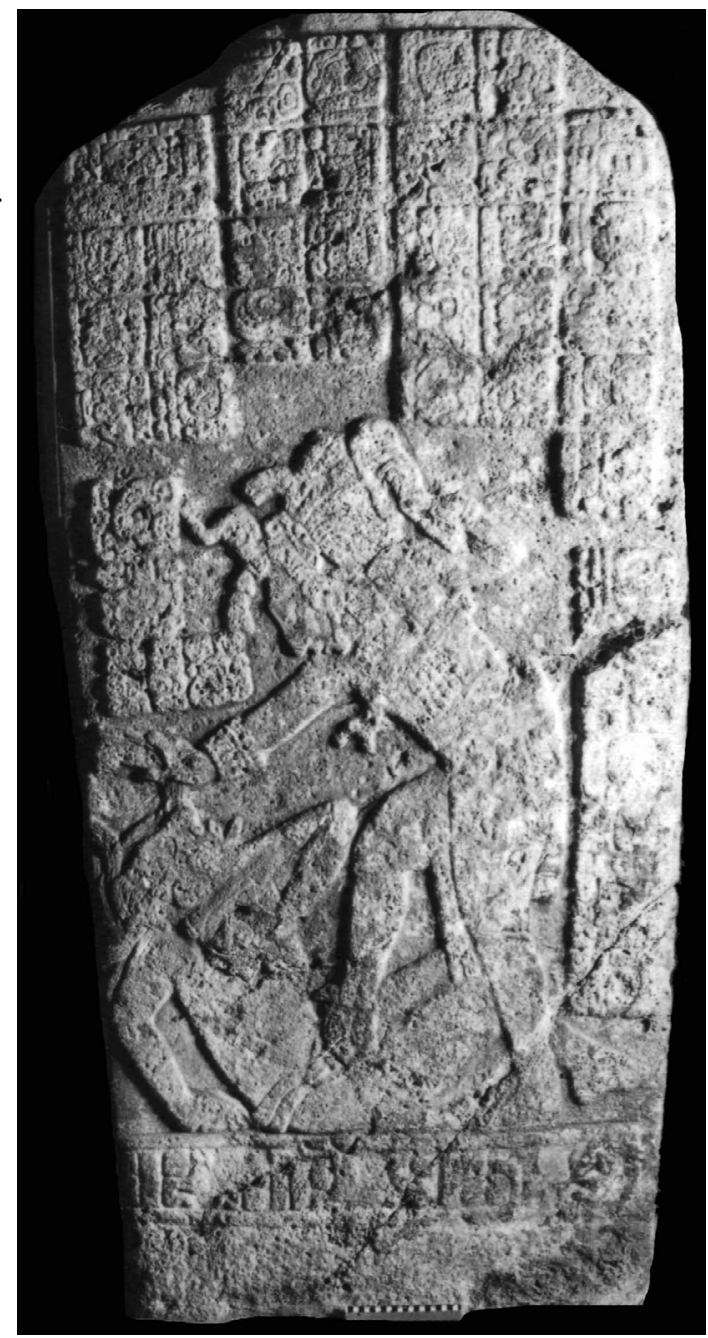

(Andrews 1943: fig. 26).

scorpion tail?
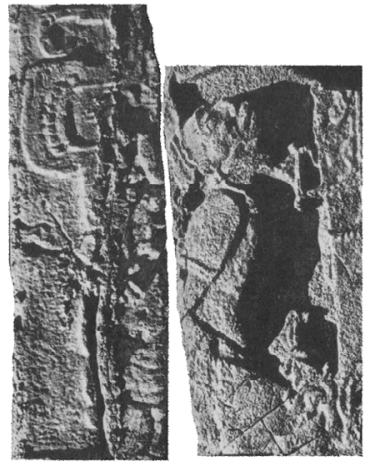

Captive duck-billed figure

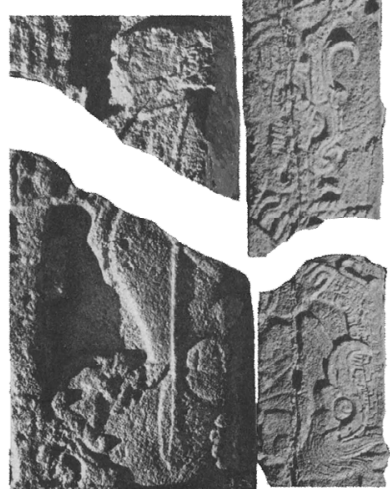

centipede tail

Captive monkey scribe
Muwaan bird 
tentative. Curving up his back and to the sides of the monument is what may be a scorpion tail. In an early photograph, his lips resemble, however, the duck bill of a wind god (Taube 2018). The far clearer example marks the individual to the right. By Maya convention, his position signals higher status. The tail is well-preserved, beginning as a muwaan bird attached to the area of his tailbone and then looping out as a centipede, ending in its open maw. Karl Taube has pointed out that this tail occurs on mythic monkeys, howlers or Alouatta pigra, with deep ties to the sun and, by extension, to the count of days, $k^{\prime}$ in (Taube cited in Newman et al. 2015: 89). He is the harbinger of dawn, then as now. For the Classic Maya, he also existed on a gradient of bestial-to-human, often with visual evidence of scribal skill. An especially early and well-preserved version was found in Burial 9 at El Diablo, an elevated acropolis within El Zotz, Guatemala (Figure 9a, upper; Newman et al. 2015: 88-95; see also $\mathrm{K} 1523$, for Late Classic example fused with the identity of the Maize God). Later versions may humanize him slightly, string the tail with eyeballs, and, most relevant, outfit him with scribal equipment, including books and brushes (Figure 9b, c, d). The example on the celebrated «Princeton vase» (K0511, Figure 9d) expresses, in my view, the decapitation of a humanoid version with snub nose, the muwaan head concealed; the same looping tail is strung with eyeballs. It is possible that the trickster rabbit, writing in a book to the side, «off-image» below, was up to some mischief. Had his tricks led to the killing of the scribe? The principal executioner appears to include a duck-billed avatar of the wind god. He is the figure leaning over, axe in hand.

The captive on Moral-La Reforma would thus seem to be a person whose identity has been fused with a mythic scribe. That role may well have accorded with his abilities prior to capture. As suggested by Miller and Johnson, scribes could be taken in battle and, in some cases, bound, displayed, and perhaps killed. The chu-ka-ja, chu$h k a j$, «is grabbed», expression above his tail (Andrews 1943: fig. 13) may refer to his actual date of capture, although the scene of possible gladiatorial activity on back muddies the story. Could these have been the two captives, forced into combat, as part of a narrative that began on the front of the stela? Or was it precisely the reverse, a bloody melee leading to the display? Reliable drawings may provide an answer.

For the Classic Maya, the existence of two identities, condensed into one person, is well-attested (Houston and Stuart 1996: 297-302). This extended to captives too, as in an example studied by Simon Martin (Miller and Martin 2004: 182). An historical figure, a lord Yax Ahk from Anaayte', probably on the Usumacinta River, was dressed as a perpetual loser, an old god of fire and darkness (Martin and Grube 2008: 182; his probable name, «Fiery Ear Jaguar», may also occur in an historical name, from a vessel in a private collection in Australia: K'AHK'-chi-ki-ni BAHLAM-[la] ma YAX-'Cord'-KAN-na; for chikin as «ear,» see Kaufman and Norman 1984: 118). In other scenes, he is crushed with stones or burned with torches held by mythic youths (Martin and Grube 2008: 82; K4118). Framing dynastic conflict with known beginnings, middles, and ends must have had its own sense of inevitability and, to winners, some degree of reassurance. At Moral-La Reforma, those roles may have involved human repositories of skill and knowledge, to the great loss of enemy kingdoms. The Princeton Vase (Figure 9d) injects another level of complexity by suggesting the involvement of a trickster rabbit, visible in the full rollout. He has taken over scribal duties while the usual person in that role is lashed like a captive and just about to lose his head. Once esteemed for his skill, the scribe is laid low, his position taken over by a mischievous rabbit. 


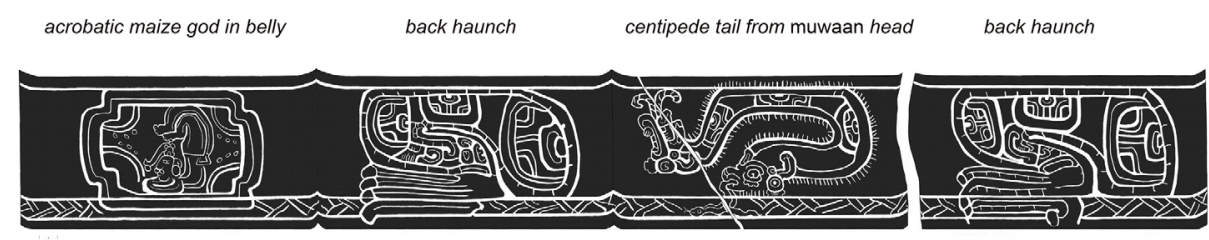

a

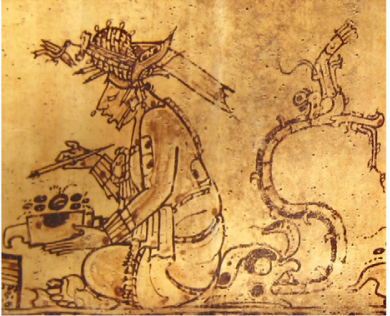

b

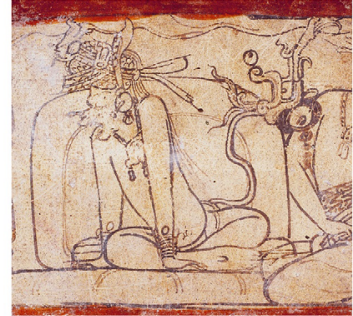

C

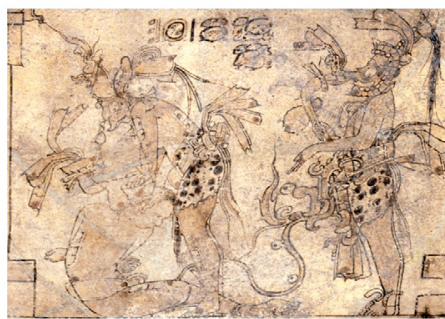

d

Figure 9. Examples of mythic howler-scribes: a) Vessel 1, Burial 9, El Diablo, c. AD 375

(drawing by Kallista Angeloff, (C) Proyecto Arqueológico El Zotz, Brown University); b) scribe with inkwell, muwaan bird head at base of centipede tail (photographer unknown); c) monkey scribe with centipede tail (K1180, (C) Justin Kerr, used with permission); and d) Princeton Vase, detail, Princeton Art Museum, y1975-17

(K511, (C) Justin Kerr, used with permission).

There are manifold needs and purposes here, worthy of Alfonso's range of interests: an ability to parse a text, as in the puzzle on the chuween vase; a demand at royal behest that subordinates should supply a key text for a dynastic monument; and a hint that scribes could be taken in battle, their identities merged with gods who, by age-old story, went from high status to low. Maya writing could be an amusing game, a political obligation, and, in its learning and practice, a deadly serious skill. Admirable for its ingenuity, writing might also trigger, perhaps, a certain ambivalence in Classic Maya minds: the capacity to make a definitive record was at once desirable and, if off-message, a source of concern.

\section{References}

Andrews, E. Wyllys. 1943. The Archaeology of Southwestern Campeche. Carnegie Institution of Washington 546. Washington, D.C.: Carnegie Institution of Washington.

Barrera Vásquez, Alfredo, Juan Ramón Bastarrachea and William Brito Sansores, eds. 1980. Diccionario Maya-Español, Español-Maya. Mérida: Ediciones Cordemex.

Boot, Erik. 2008. «At the Court of Itzam Nah Yax Kokaj Mut: Preliminary Iconographic and Epigraphic Analysis of a Late Classic Vessel». http://www.mayavase.com/God-D-CourtVessel.pdf. 
Caminos, Ricardo. 1976. The Recording of Inscriptions and Scenes in Tombs and Temples. New York: Metropolitan Museum of Art.

Christenson, Allen J. 2007. Popol Vuh: The Sacred Book of the Maya. Norman: University of Oklahoma Press.

Coe, Michael D. and Stephen Houston. 2015. The Maya. 9th edition. London: Thames and Hudson.

Cooley, Alison E. 2012. The Cambridge Manual of Latin Epigraphy. Cambridge: Cambridge University Press.

Flier, Michael S. 2008. «Church of Intercession on the Moat / St. Basil's Cathedral», in Picturing Russia: Explorations in Visual Culture, Valerie A. Kivelson and Joan Neuberger, eds., pp. 42-46. New Haven: Yale University Press.

Graham, Ian. 1975. Corpus of Maya Hieroglyphic Inscriptions, Volume 1: Introduction. Cambridge: Peabody Museum of Archaeology and Ethnology, Harvard University.

- 1982. Corpus of Maya Hieroglyphic Inscriptions, Volume 3, Part 1: Yaxchilan. Cambridge: Peabody Museum of Archaeology and Ethnology, Harvard University.

Griffiths, J. Gwyn. 1971. «'Arepo' in the Magic 'Sator' Square». The Classical Review 21: 6-8.

Grube, Nikolai. 1998. «Speaking through Stones: A Quotative Particle in Maya Hieroglyphic Inscriptions», in 50 años de estudios americanistas en la Universidad de Bonn, Sabine Dedenbach-Salazar Sáenz, Carmen Arellano Hoffmann, Eva Konig and Heiko Prumers, eds., pp. 543-58. Markt Schwaben: Verlag Anton Sauerwein.

Hopkins, Nicholas A., J. Kathryn Josserand and Ausencio Cruz Guzmán. 2011. A Historical Dictionary of Chol (Mayan): The Lexical Sources from 1789 to 1935. http://www.famsi. org/mayawriting/dictionary/hopkins/CholDictionary2010.pdf.

Houston, Stephen D. 1993. Hieroglyphs and History at Dos Pilas: Dynastic Politics of the Classic Maya. Austin: University of Texas Press.

. 2014. «Monuments», in Life and Politics at the Royal Court of Aguateca: Artifacts, Analytical Data, and Synthesis, Takeshi Inomata and Daniela Triadan, eds., pp. 235-257. Aguateca Archaeological Project First Phase Monograph Series 3. Salt Lake City: University of Utah Press.

- 2016a. «Crafting Credit: Authorship among Classic Maya Painters and Sculptors», in Making Value, Making Meaning: Techné in the Pre-Columbian World, Cathy L. Costin, ed., pp. 391-431. Washington, D.C.: Dumbarton Oaks Research Library and Collection.

- 2016b. «Gladiatrix». Maya Decipherment: Ideas on Ancient Maya Writing and Iconography, https://decipherment.wordpress.com/2016/06/08/gladiatrix/.

- 2018. The Gifted Passage: Young Men in Classic Maya Art and Text. New Haven: Yale University Press.

Houston, Stephen D. and David Stuart. 1993. «Multiple Voices in Maya Writing: Evidence for First- and Second-Person References». Paper presented at the 58th meeting of the Society for American Archaeology, St. Louis.

- 1996. «Of Gods, Glyphs, and Kings: Divinity and Rulership among the Classic Maya». Antiquity 70 (268): 289-312.

Houston, Stephen, David Stuart and Karl Taube. 2006. The Memory of Bones: Body, Being, and Experience among the Classic Maya. Austin: University of Texas Press.

Howse, Christopher. 2015. «Unique Ancient Sator-Rotas Word-Square Discovered». The Telegraph, 02 May 2015. https://www.telegraph.co.uk/comment/11579586/Unique-ancientSator-Rotas-word-square-discovered.html. 
Hull, Kerry M. 2016. A Dictionary of Ch'orti'Mayan-Spanish-English. Salt Lake City: University of Utah Press.

Hull, Kerry, Michael D. Carrasco and Robert Wald. 2009. «The First-Person Singular Independent Pronoun in Classic Ch'olan». Mexicon XXXI (2): 36-43.

Johnston, Kevin. 2001. «Broken Fingers: Classic Maya Capture and Polity Consolidation». Antiquity 75 (288): 373-381.

Kaufman, Terrence S. and William M. Norman. 1984. «An Outline of Proto-Cholan Phonology, Morphology, and Vocabulary», in Phoneticism in Mayan Hieroglyphic Writing, John S. Justeson and Lyle Campbell, eds., pp. 77-166. Institute for Mesoamerican Studies 9. Albany: State University of New York.

Last, Hugh. 1952. «The Rotas-Sator Square: Present Position and Future Prospects». Journal of Theological Studies 3 (1): 92-97.

Law, Danny. 2014. Language Contact, Inherited Similarity and Social Difference: The Story of Linguistic Interaction in the Maya Lowlands. Amsterdam: John Benjamins.

Marcus, Joyce. 1987. The Inscriptions of Calakmul: Royal Marriage at a Maya City in Campeche, Mexico. Technical Report 21. Ann Arbor: Museum of Anthropology, University of Michigan.

Martin, Simon. 2003. «Moral-Reforma y la contienda por el oriente de Tabasco». Arqueología Mexicana 61: 44-47.

- 2014. The Classic Maya Polity: An Epigraphic Approach to Reconstructing a PreHispanic Political System. Doctoral Thesis. University College London.

Martin, Simon and Nikolai Grube. 2008. Chronicle of the Maya Kings and Queens: Deciphering the Dynasties of the Ancient Maya. 2nd ed. London: Thames and Hudson.

Martin, Simon, Stephen Houston and Marc Zender. 2015. «Sculptors and Subjects: Notes on the Incised Text of Calakmul Stela 51». Maya Decipherment: Ideas on Ancient Maya Writing and Iconography, https://decipherment.wordpress.com/2015/01/07/sculptors-andsubjects-notes-on-the-incised-text-of-calakmul-stela-51/.

Miller, Mary. 2000. «Guerra y escultura maya: un argumento en favor del tributo artístico», in La guerra entre los antiguos mayas: Memoria de la Primera Mesa Redonda de Palenque, Silvia Trejo, ed., pp. 176-187. Mexico: CONACULTA, Instituto Nacional de Antropología e Historia.

Miller, Mary and Claudia Brittenham. 2013. The Spectacle of the Late Maya Court: Reflections on the Murals of Bonampak. Austin and Mexico: University of Texas Press, CONACULTA, Instituto Nacional de Antropología e Historia.

Miller, Mary and Simon Martin. 2004. Courtly Art of the Ancient Maya. San Francisco: Fine Arts Museum of San Francisco.

Mora-Marín, David F. 2009. «Reconstruction of Proto-Ch'olan Independent Pronouns: Grammaticalization and Evidence for Sociolinguistic Variation». Transactions of the American Philological Society 107 (1): 98-129.

Newman, Sarah, Stephen Houston, Thomas Garrison and Edwin Román. 2015. «Outfitting a Ruler», in Temple of the Night Sun: A Royal Tomb at El Diablo, Guatemala, Stephen Houston, Sarah Newman, Edwin Román and Thomas Garrison, eds., pp. 84-179. San Francisco: Precolumbia Mesoweb Press.

Pavón Abreu, Raúl. 1945. Morales, una importante ciudad arqueológica en Tabasco. Cuadernos 6. Campeche: Gobierno del Estado de Campeche.

Robertson, John, Stephen Houston, Marc Zender and David Stuart. 2007. Universals and the Logic of the Material Implication: A Case Study from Maya Hieroglyphic Writing. 
Research Reports on Ancient Maya Writing 62. Washington, D.C. and Austin: Center for Maya Research and the Mesoamerica Center, University of Texas at Austin.

Ruppert, Karl and John H. Denison, Jr. 1943. Archaeological Reconnaissance in Campeche, Quintana Roo, and Petén. Carnegie Institution of Washington 543. Washington, D.C.: Carnegie Institution of Washington.

Schele, Linda and Mary E. Miller. 1986. The Blood of Kings: Dynasty and Ritual in Maya Art. Fort Worth: Kimbell Art Museum.

Scholes, France V. and Ralph L. Roys. 1968. The Maya Chontal Indians of Acalan-Tixchel: A Contribution to the History and Ethnography of the Yucatan Peninsula. Norman: University of Oklahoma Press. [First published as 1948, Carnegie Institution of Washington 560].

Stone, Andrea J. 1995. Images from the Underworld: Naj Tunich and the Tradition of Maya Cave Painting. Austin: University of Texas Press.

Stuart, David. 1989. «Hieroglyphs on Maya Vessels», in The Maya Vase Book: A Corpus of Rollout Photographs of Maya Vases 1, Justin Kerr, ed. pp. 149-160. New York: Kerr Associates.

- 1998. «'The Fire Enters His House': Architecture and Ritual in Classic Maya Texts», in Function and Meaning in Classic Maya Architecture, Stephen D. Houston, ed., pp. 373-425. Washington, D.C.: Dumbarton Oaks Research Library and Collection.

Stuart, David and Stephen D. Houston. 1994. Classic Maya Place Names. Studies in PreColumbian Art and Archaeology 33. Washington, D.C.: Dumbarton Oaks.

Taube, Karl A. 2018. «Orígenes y simbolismo de la deidad del viento en Mesoamérica». Arqueología Mexicana 152: 34-39.

Taube, Karl and Marc Zender. 2009. «American Gladiators: Ritual Boxing in Ancient Mesoamerica», in Blood and Beauty: Organized Violence in the Art and Archaeology of Mesoamerica and Central America, Heather Orr and Rex Koontz, eds., pp. 161-220. Los Angeles: Cotsen Institute of Archaeology Press, University of California.

Turchi, Peter. 2014. A Muse and a Maze: Writing as Puzzle, Mystery, and Magic. San Antonio: Trinity University Press.

Vértes, Krisztián. 2014. Digital Epigraphy. Chicago: Epigraphic Survey, Oriental Institute, University of Chicago. https://oi.uchicago.edu/sites/oi.uchicago.edu/files/uploads/shared/ docs/Digital-Epigraphy.pdf.

Vinel, Nicolas. 2006. «Le judaïsme caché du carré Sator de Pompéi». Revue de l'histoire des religions 223 (2): 173-194.

Williams, Charles K. 2001. «War». The New Yorker Nov. 5: 80-81.

Zender, Marc, Dmitri Beliaev and Albert Davletshin. 2016. «The Syllabic Sign we and an Apologia for Delayed Decipherment». The PARI Journal 17 (2): 35-56. 